
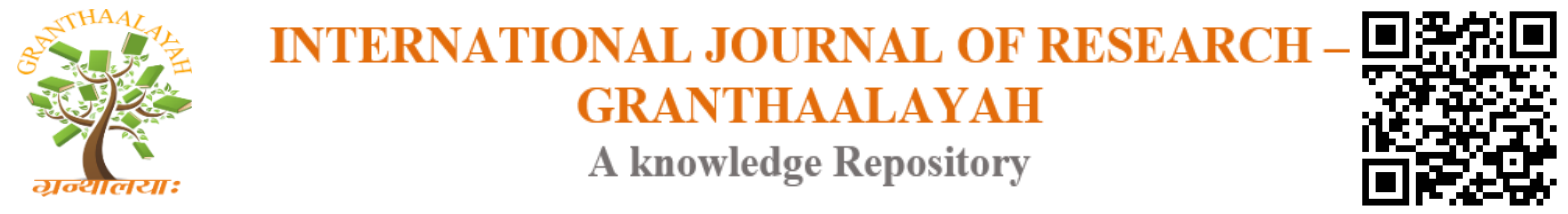

Management

\title{
EFFECT OF ORGANIZATIONAL CULTURE, WORK COMMITMENT AND MANAGEMENT KNOWLEDGE ON EMPLOYEE ACHIEVEMENT MOTIVATION IN THE ENVIRONMENT MINISTRY OF RELIGION OF JAMBI PROVINCE
}

\author{
Mukhtar ${ }^{1}$, Risnita ${ }^{2}$, Nurazmi ${ }^{3}$ \\ ${ }^{1}$ Professor at State Islamic University SulthanThahaSaifuddin Jambi Indonesia \\ ${ }^{2}$ Deputy Director of Postgraduate and Lecturers at State Islamic University Sulthan Thaha \\ Saifuddin Jambi Indonesia \\ ${ }^{3}$ Postgraduate Student Doctoral Program in Islamic Education Management UIN Sulthan Thaha \\ Syaifuddin Jambi
}

\begin{abstract}
This study aims to examine the effect of exogenous variables on endogenous variables either partially or simultaneously. The research objectives were arranged as many as 10 points. The research location in the Office of the Ministry of Religion of Jambi Province which consists of the Ministry of Religion office in Jambi City, the Office of the Ministry of Religion of TanjungJabungTimur, the Office of the Ministry of Religion of the Regency of Batanghari.

This study produces ten conclusions, namely, including: 1). There is a direct influence of organizational culture $\left(\mathrm{X}_{1}\right)$ on employee achievement motivation (X4). Based on the results of the calculation of the analysis obtained tcount $(18,31)>t$ table (1.969), so that H0 is rejected and H1 is accepted. It means that organizational culture has a significant influence on employee achievement motivation. 2). There is a direct effect of work commitment $\left(\mathrm{X}_{2}\right)$ on employee achievement motivation $\left(\mathrm{X}_{4}\right)$. Based on the results of the calculation of the analysis obtained the value of tcount (7.61)> t table (1.969), so that $\mathrm{H} 0$ is rejected and $\mathrm{H} 1$ is accepted. It means that the work commitment that develops in the institution has a significant influence on employee achievement motivation. 3). There is a direct influence of organizational culture $\left(\mathrm{X}_{1}\right)$ and work commitment $\left(\mathrm{X}_{2}\right)$ on employee achievement motivation $\left(\mathrm{X}_{4}\right)$. Based on the results of the calculation of the analysis obtained the value of Fcount (16.36) >Ftable (3.45), so that H0 is rejected and $\mathrm{H} 1$ is accepted. Meaning that the organizational culture and high management knowledge in the institution have a significant influence on employee achievement motivation. The conclusion of the study is, from the results of testing the hypothesis, it can be concluded that the 10 hypotheses are accepted, namely there are effects of exogenous variables on endogenous variables both partially and simultaneously, both directly and indirectly. The research implication is that an employee's achievement motivation is strongly influenced by organizational culture, work commitment, and management knowledge, the better the organizational culture, the higher the work commitment and management knowledge, the higher the spirit of achievement in carrying out a job.
\end{abstract}


Keywords: Organizational Culture; Work Commitment; Management Knowledge; and Achievement Motivation.

Cite This Article: Mukhtar, Risnita, and Nurazmi. (2019). "EFFECT OF ORGANIZATIONAL CULTURE, WORK COMMITMENT AND MANAGEMENT KNOWLEDGE ON EMPLOYEE ACHIEVEMENT MOTIVATION IN THE ENVIRONMENT MINISTRY OF RELIGION OF JAMBI PROVINCE." International Journal of Research - Granthaalayah, 7(7), 106-117. https://doi.org/10.29121/granthaalayah.v7.i7.2019.731.

\section{Introduction}

Achievement Motivation According to McClelland is an effort to achieve success or success in competition with a measure of excellence that can be in the form of other people's achievements or their own achievements. Achievement motivation is an impetus related to how to do things better, faster, more efficiently than what has been done before, as an effort to achieve success or success in competition with a measure of excellence that can be in the form of other people's achievements or own achievements. The indicators of employee achievement motivation are: 1) superior achievement, 2) independence, 3) responsibility, 4) hard working), 5) visionary, 6) optimistic, 7) superior competing.

In a person's daily life before having motivation, it will be preceded by a motive that is on him. Fulfillment of motivational needs is inevitable for all employees because if motivation is properly fulfilled, job satisfaction will emerge in the next turn, will have an impact on the peace of work. Motivation can be in the form of finance and non-finance which will have an impact on work calm.

Likewise, the achievement motivation of employees in the Office of the Ministry of Religion of Jambi Province. The results of the initial survey through the dissemination of instruments on employee achievement motivation with indicators: 1) superior achievement, 2) independence, 3) responsibility, 4) working hard), 5) visionary, 6) optimistic, 7) superior competitiveness, in research social situations namely Office of the Ministry of Religion of the City of Jambi with respondents 30 employees obtained data as follows:

Dissemination Results of Employee Achievement Motivation Variables in the office of the Ministry of Religion of the City of Jambi in 2017

\begin{tabular}{|l|l|c|c|c|c|c|c|}
\hline \multirow{2}{*}{ No } & \multirow{2}{*}{ Indikator } & \multicolumn{5}{|c|}{ Penilaian } & \multirow{2}{*}{ Jml } \\
\cline { 3 - 7 } & & SL & SR & KD & JR & TP & \\
\hline 1. & Superior achievement & $10 \%$ & $60 \%$ & $20 \%$ & $5 \%$ & $5 \%$ & $100 \%$ \\
\hline 2. & Independence & $15 \%$ & $50 \%$ & $15 \%$ & $15 \%$ & $5 \%$ & $100 \%$ \\
\hline 3. & Responsible & $50 \%$ & $35 \%$ & $5 \%$ & $5 \%$ & $5 \%$ & $100 \%$ \\
\hline 4. & Work hard & $15 \%$ & $55 \%$ & $20 \%$ & $5 \%$ & $5 \%$ & $100 \%$ \\
\hline 5. & Visioner & $20 \%$ & $45 \%$ & $15 \%$ & $15 \%$ & $5 \%$ & $100 \%$ \\
\hline 6. & Optimis & $10 \%$ & $50 \%$ & $20 \%$ & $15 \%$ & $5 \%$ & $100 \%$ \\
\hline 7. & Superior competition & $10 \%$ & $40 \%$ & $20 \%$ & $20 \%$ & $10 \%$ & $100 \%$ \\
\hline
\end{tabular}

Based on table 1 through questionnaires, it can be seen that the employee achievement motivation of the Jambi City Ministry of Religion office can be seen based on the indicators of employee 
achievement motivation as follows: 1). Superior achievement $60 \%$ of respondents stated often, this meant good, 2). 50\% independence states often and $15 \%$ states always, this means good, 3 ). responsibility 50\% always means good, 4). Working hard 55\% which states often, this means good, 5). visionary $45 \%$ said often, 6) optimistic 50\% said often, 7) competing superior $40 \%$ said often, this means both of the 7 indicators that exist, can be seen 6 indicators that fall into the frequent category and 1 indicator in the category always means this frequent number also close to the number that is always so that it needs more maximal efforts to increase employee achievement motivation in carrying out the task. Based on the results of filling out the questionnaire and calculated based on the scoring guidelines, it can be understood that employee achievement motivation in the Ministry of Religion's office is in the good category.

In the research social situation, namely the Ministry of Religion Office of Tebo Regency with respondents 30 employees obtained data as follows:

Dissemination Results of Employee Achievement Motivation Variables in the office of the Ministry of Religion in Tebo Regency in 2017

\begin{tabular}{|l|l|l|l|l|l|l|l|}
\hline \multirow{2}{*}{ No } & \multirow{2}{*}{ Indikator } & \multicolumn{5}{|c|}{ Penilaian } & \multirow{2}{*}{ Jml } \\
\cline { 3 - 7 } & & SL & SR & KD & JR & TP & \\
\hline 1. & Superior achievement & $10 \%$ & $55 \%$ & $15 \%$ & $5 \%$ & $5 \%$ & $100 \%$ \\
\hline 2. & Independence & $40 \%$ & $40 \%$ & $10 \%$ & $5 \%$ & $5 \%$ & $100 \%$ \\
\hline 3. & Responsible & $40 \%$ & $45 \%$ & $5 \%$ & $5 \%$ & $5 \%$ & $100 \%$ \\
\hline 4. & Work hard & $15 \%$ & $50 \%$ & $15 \%$ & $5 \%$ & $5 \%$ & $100 \%$ \\
\hline 5. & Visioner & $10 \%$ & $50 \%$ & $15 \%$ & $15 \%$ & $10 \%$ & $100 \%$ \\
\hline 6. & Optimis & $15 \%$ & $45 \%$ & $20 \%$ & $15 \%$ & $5 \%$ & $100 \%$ \\
\hline 7. & Superior competition & $10 \%$ & $50 \%$ & $15 \%$ & $15 \%$ & $10 \%$ & $100 \%$ \\
\hline
\end{tabular}

Based on table 2 through questionnaires, it can be seen that the achievement motivation of the employees of the Ministry of Religion Office in Tebo Regency can be seen based on the indicators of employee achievement motivation as follows: 1). Superior achievement $55 \%$ of respondents stated often, this meant good, 2). independence $40 \%$ states often and $15 \%$ states always, this means good, 3). responsibility $45 \%$ e means always means very good, 4). Working hard $50 \%$ which states often, this means good, 5). visionary 50\% said often, 6) optimistic this $45 \%$ said often, 7) competing superior $50 \%$ said often, this means that of the 7 indicators available, it could be seen that 5 indicators were included in the category often and 2 indicators were categorized as frequent figures also close to rare numbers so that more maximal efforts are needed to increase employee achievement motivation in carrying out tasks. Based on the results of filling out the questionnaire and calculated based on the scoring guidelines, it can be understood that employee achievement motivation in the Ministry of Religion's office is in the good category.

In the research social situation, namely the Office of the Ministry of Religion, TanjungJabungTimur Regency with respondents 30 employees obtained data as follows: 
Dissemination Results of Employee Achievement Motivation Variables at the Ministry of Religion office in TanjungJabungTimur Regency in 2017

\begin{tabular}{|l|l|c|c|c|c|c|c|}
\hline \multirow{2}{*}{ No } & \multirow{2}{*}{ Indikator } & \multicolumn{5}{|c|}{ Penilaian } & \multirow{2}{*}{ Jml } \\
\cline { 3 - 7 } & & SL & SR & KD & JR & TP & \\
\hline 1. & Superior achievement & $10 \%$ & $55 \%$ & $10 \%$ & $10 \%$ & $5 \%$ & $100 \%$ \\
\hline 2. & Independence & $15 \%$ & $60 \%$ & $10 \%$ & $10 \%$ & $5 \%$ & $100 \%$ \\
\hline 3. & Responsible & $10 \%$ & $50 \%$ & $30 \%$ & $5 \%$ & $5 \%$ & $100 \%$ \\
\hline 4. & Work hard & $20 \%$ & $50 \%$ & $20 \%$ & $5 \%$ & $5 \%$ & $100 \%$ \\
\hline 5. & Visioner & $10 \%$ & $50 \%$ & $20 \%$ & $15 \%$ & $5 \%$ & $100 \%$ \\
\hline 6. & Optimis & $15 \%$ & $45 \%$ & $25 \%$ & $10 \%$ & $5 \%$ & $100 \%$ \\
\hline 7. & Superior competition & $10 \%$ & $50 \%$ & $15 \%$ & $20 \%$ & $5 \%$ & $100 \%$ \\
\hline
\end{tabular}

Based on table 3 through questionnaires, the district can be seen based on indicators of employee achievement motivation as follows: 1). Superior achievement 55\% of respondents stated often, this meant good, 2). independence $60 \%$ states often and $15 \%$ states always, this means good, 3 ). $50 \%$ responsibility means often means good, 4). Working hard 50\% which states often, this means good, 5). visionary 50\% said often, 6) optimistic this $45 \%$ said often, 7) competing superior 50\% said often, it could be seen that this number often approaches rare numbers so that the maximum efforts are needed to increase the employee achievement motivation in carrying out their duties. Based on the results of this study, the employee is in the good category.

\section{Foundation of Theory, Thinking Framework, Research Hypotheses}

\subsection{Employee Achievement Motivation (X4)}

According to Heckhausen (1967: 54) achievement motives are interpreted as attempts to increase or carry out personal skills as high as possible in all activities and a measure of excellence is used as a comparison, although there are two possibilities in doing these activities, namely failure or success. Furthermore, he explained that achievement motivation is a motive that encourages individuals to achieve success and aims to succeed in competition with several standard of excellence. The measure of excellence is used for the standard of achievement of self-achieved achievement before and is feasible as in a competition.

In expectancy-value theory Atkinson (1960: 56) suggests that a person's achievement motivation is based on two things, namely, the tendency to succeed and the tendency to avoid failure. Basically the state of the motive is owned by individuals, but both have different circumstances in various situations and conditions according to the existence of achievements. More clearly Atkinson (1958: 34) argues that individual success to achieve success and win competition based on excellence standards is strongly related to personality types that have higher achievement motives than motives to avoid failure as well as vice versa, if the motive avoids failure is higher than the motive for success, then someone's achievement motivation tends to be low. From this description it can be concluded that achievement motivation is an impetus related to how to do things better, faster, more efficiently than what has been done before, as an effort to achieve success or success in competition with a measure of excellence that can be other people's achievements or their own achievements. 


\subsection{Organizational Culture (X1)}

Organizational culture becomes the norm, trust, value and practice to all members of the organization. This includes the ways a person communicates within an organization such as calling on the name of a colleague, how to talk, dress, work values, and so on. The birth of a positive or negative organizational culture depends on the policies of the management or the leadership of the organization. Organizational culture is actually very complex and there needs to be shared values and norms that guide members' behavior.

Luthans said that organizational culture must have a recognized and valued characteristic of regularity, the existence of norms, dominant values, philosophy, rules and organizational atmosphere. Stephen P. Robbins explains that organizational culture is a value system held and carried out by members of the organization, so that such things can distinguish the organization from other organizations.

Furthermore, Stephen P. Robbins suggests that there are seven elements that show the characteristics of organizational culture, namely: a) innovation and risk taking (innovation and risk taking), b) attention to detail (attention to details), c) outcome orientation (orientation on benefits), d) people orientation (orientation to people), e) team orientation (team orientation), f) aggressiveness (aggressiveness), and g) stability (stability). Organizational culture according to Kreitner and Kinicki has four functions, namely 1) organizational culture will provide its members with organizational identity, 2). Provide facilities in joint commitment, 3) support a stable social system and 4) shape the behavior of its members with sensitivity to their environment.

\subsection{Work Commitments(X2)}

Commitment is an attitude that reflects employee loyalty to the organization and to an ongoing process where members of the organization express their concern for the organization and continued success and progress. Meyer and Allen's commitment has three dimensions, namely effective commitment, continuity commitment and normative commitment. In this case the guidelines for increasing organizational commitment are: a) Commit to the core values of humans, b) Clarify and communicate your mission, b) Ensure organizational justice, c) Create a sense of community, and d) Support employee development.

Commitment is the foundation for achieving success in every organization and is the partner of every organization in achieving each goal that has been determined whether an organization is located in a high or low level of commitment. The purpose of an organization is a fundamental element, because the goal is the goal that must be achieved by the organization, including its members. In addition, human resources are also important elements because they are the driving force of the organization in achieving its goals, because the success of the organization today depends on its success in outlining tasks and maximizing the capabilities of its members.

Conceptually, there are three factors that influence commitment: 1) a strong belief in and acceptance of the organization's goals (a strong belief and acceptance of goals and objectives and organizational values), 2) a person's willingness to exert considerable effort on the name of the organization, and (willingness to carry out efforts for the benefit of the organization), and 3) 
definite person desire to maintain membership (there is a strong desire to maintain membership in the organization).

\subsection{Management Knowledge (X3)}

Knowledge has several definitions, Nonaka and Takeuchi define knowledge as a justified true belief. Nonaka and Takeuchi focus the definition of knowledge on personal beliefs and emphasize the importance of justification. Davenport and Prusak in Pramudya define knowledge as a fluid mix of framed experience, values, contextual information, and expert insight that provides a framework for evaluating and incorporating new experiences and information. It originated and was applied in the minds of knowers. In organization, it often becomes not only in documents or repositories but also in organizational routines, processes, practices, and norms. Furthermore Zeleny and Wang in Pramudya define knowledge as a purposeful coordination of actions. O'Dell et.al on Turban states knowledge as knowledge in action.

The nature of knowledge according to Suriamantri is that everything we know about a particular object from knowledge itself is a treasure of mental wealth that directly or indirectly contributes to enriching our lives. According to Rich knowledge classified into five major parts, namely: 1) practical knowledge, 2) intellectual knowledge, 3) small talk, 4) spiritual knowledge, and 5) unknown knowledge (unwanted knowledge).

According to Sutrisno, as a manager, the principal must at least be able to carry out seven managerial activities, the seven activities are as follows: 1) making predictions, 2) innovating, 3) creating strategies or policies to succeed innovative minds, 4) compiling planning, 5) finding educational resources, 6) providing educational facilities, 7) exercising control or control. Broadly speaking, a school principal must know and be able to carry out management functions. The management function according to Stoner is 1) planning, 2) organizing, 3) leading, and 4) controlling. The success of the organization depends on the four management functions that must be implemented as well as possible.

\subsection{Research Hypotheses}

Based on the exposure of the theoretical foundation used and the frame of mind, the research hypothesis can be formulated as follows:

1) There is an influence of organizational culture (X1) on employee achievement motivation (X4)

2) There is the influence of work commitment (X2) on employee achievement motivation (X4)

3) There is the influence of organizational culture (X1) and work commitment (X2) on employee achievement motivation (X4)

4) There is an influence of organizational culture (X1) on management knowledge (X3)

5) There is the effect of work commitment (X2) on management knowledge (X3)

6) There is an influence of organizational culture (X1) and work commitment (X2) to directly influence management knowledge (X3)

7) There is the influence of achievement motivation (X3) on employee achievement motivation (X4) 
8) There is the influence of organizational culture (X1) and work commitment (X2) through management knowledge (X3) on achievement motivation

9) There is the influence of organizational culture (X1) through management knowledge (X3) on achievement motivation (X4)

10) There is an influence of organizational culture (X1), work commitment (X2) and management knowledge (X3) simultaneously on employee achievement motivation (X4)

\section{Research Methodology}

This study uses a quantitative research approach. According to Creswell "Quantitative research is a type of educational research in which the researcher decides what to study, asks for specifics, narrow questions, collect quantifiable data for participants, analyzes these numbers using statistics and conducts the inquiry in unbiased, objective manner. Quantitative research is methods for testing certain theories by examining relationships between variables. These variables are measured using research instruments, so data consisting of numbers can be analyzed based on statistical procedures.

According to Sugiono quantitative research is research based on the philosophy of positivism, used to examine certain populations or samples, sampling techniques are generally done randomly, data collection uses research instruments, data analysis is quantitative / statistical in order to test predetermined hypotheses.

Based on the problem and purpose, the method used in this study is a survey method of causal relationships, which will test the pattern of relationships and direct and indirect effects, between exogenous variables (organizational culture X1, X2 work commitment, and management knowledge $\mathrm{X} 3$ ), towards endogenous variables (X4 achievement motivation).

The path analysis model of each direct influence variable or indirect influence in the study can be seen in the following constellations:

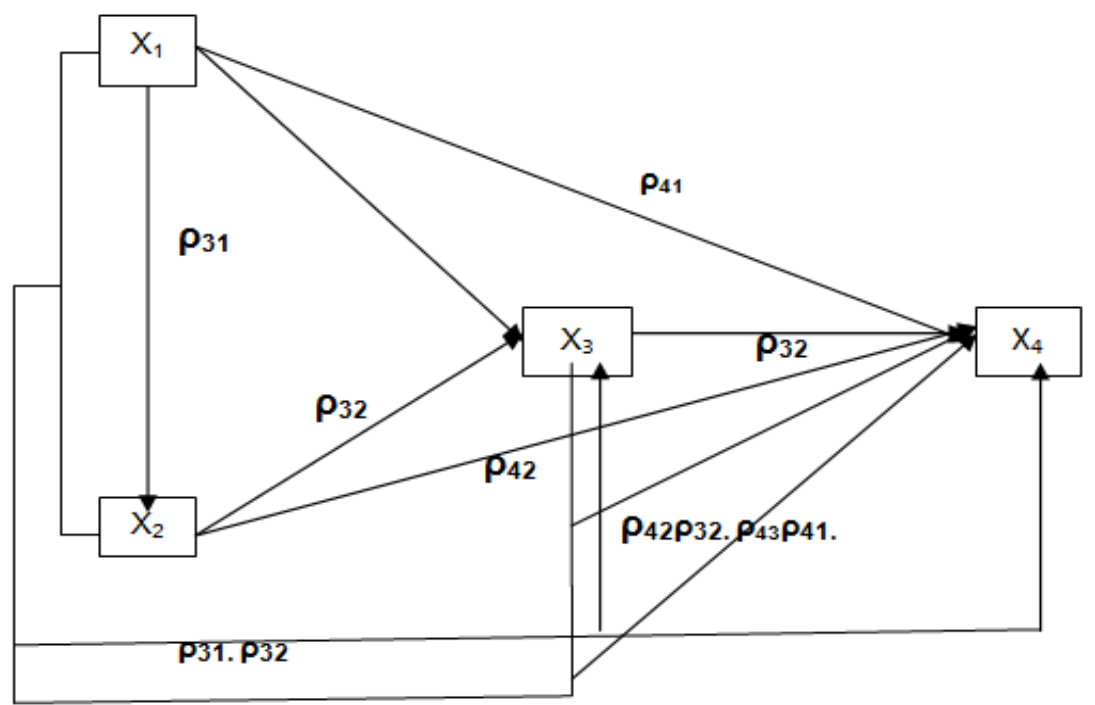

Path Analysis Constellation relationship between X1, X2, X3 and X4. 
Information:

$\mathrm{X} 1$ = Organizational culture

$\mathrm{X} 2$ = Work Commitment

X3 = Management Knowledge

X4 = Achievement Motivation

\section{Location Description, Research Results and Research Discussion}

\subsection{Location Description}

Since the issuance of Presidential Decree No. 49 of 2002 concerning the Ministry of Religion and KMA No. 373 of 2002, the organizational structure of the Jambi Ministry of Religion Office was included in the Typology I-A. Based on the data until September 1, 2012, there were 60 Ministry of Religion employees in the City of Jambi, who were spread in work units according to their respective duties.

In line with one of Indonesia's long-term missions to create a noble, moral, ethical, cultured, and civilized society based on the Pancasila philosophy and vision of the Ministry of Religion, namely the Realization of a Religion, Advanced, Prosperous and Smart Indonesian Society and Respect for Each Other Adherents of Religion in Community Life, Nation and State in the Container of the Unitary State of the Republic of Indonesia. While the Regional Office of the Ministry of Religion of Jambi has formulated the following vision; "The realization of the Jambi community who are religious, harmonious, intelligent, harmonious, independent, as well as born and spiritual"

Based on PMA 13 of 2012 concerning the Organization and Work Procedure of Vertical Agencies of the Ministry of Religion, the Office of the Ministry of Religion of BatangHari Regency including in the I-A Typology for that in addition to the above main tasks also has the function of carrying out activities with organizational potential.

\subsection{Research Results}

The research data in the form of questionnaire results from the independent variables, namely organizational culture variables, work commitment and management knowledge variables on the dependent variable is employee achievement motivation. In this study a sample of 90 employees was used, namely the Ministry of Religion of Jambi City, employees of the Ministry of Religion Office of Batanghari Regency and Employees of the Ministry of Religion Office of TanjungJabungTimur Regency in the form of: highest score, lowest score, mean (M), and standard deviation (SD), b) calculation of analysis requirements: normality test, homogeneity test, and linearity test, and c) hypothesis testing. Data processing is done manually and with SPSS Version 22.00. Complete data on summary scores for each variable can be seen in table below. 
Summary Descriptive Table Descriptive Statistics Four variables

\begin{tabular}{|c|c|c|c|c|}
\hline \multicolumn{5}{|c|}{ Statistics } \\
\hline & $\begin{array}{l}\text { X1_Budaya } \\
\text { Organisasi }\end{array}$ & $\underset{\text { Kerja }}{\text { X2_Komitmen }}$ & $\begin{array}{c}\text { X3_Pengetahuan } \\
\text { Manajemen }\end{array}$ & $\begin{array}{c}\text { X4_Motivasi } \\
\text { Berprestasi }\end{array}$ \\
\hline \begin{tabular}{|l|} 
Valid \\
\end{tabular} & 90 & 90 & 90 & 90 \\
\hline${ }^{N}$ Missing & 0 & 0 & 0 & 0 \\
\hline Mean & 126.48 & 112.63 & 19.50 & 127.33 \\
\hline Median & 128.50 & 112.50 & 19.50 & 128.00 \\
\hline Mode & 127.3 & 112.5 & 19.50 & 128 \\
\hline \begin{tabular}{|l} 
Std. \\
Deviation
\end{tabular} & 8.17 & 10.29 & 5.29 & 14.23 \\
\hline Range & 40 & 54 & 27 & 76 \\
\hline Minimum & 106 & 85 & 6 & 90 \\
\hline Maximum & 146 & 139 & 33 & 166 \\
\hline Sum & 11383 & 10137 & 1755 & 11460 \\
\hline
\end{tabular}

Based on the two path coefficient calculations above, the Work Commitment (X2) variable on Achievement Motivation (X4) through Knowledge Management (X3) is $87.7 \%$ while the remaining $12.3 \%$ is influenced by other variables.

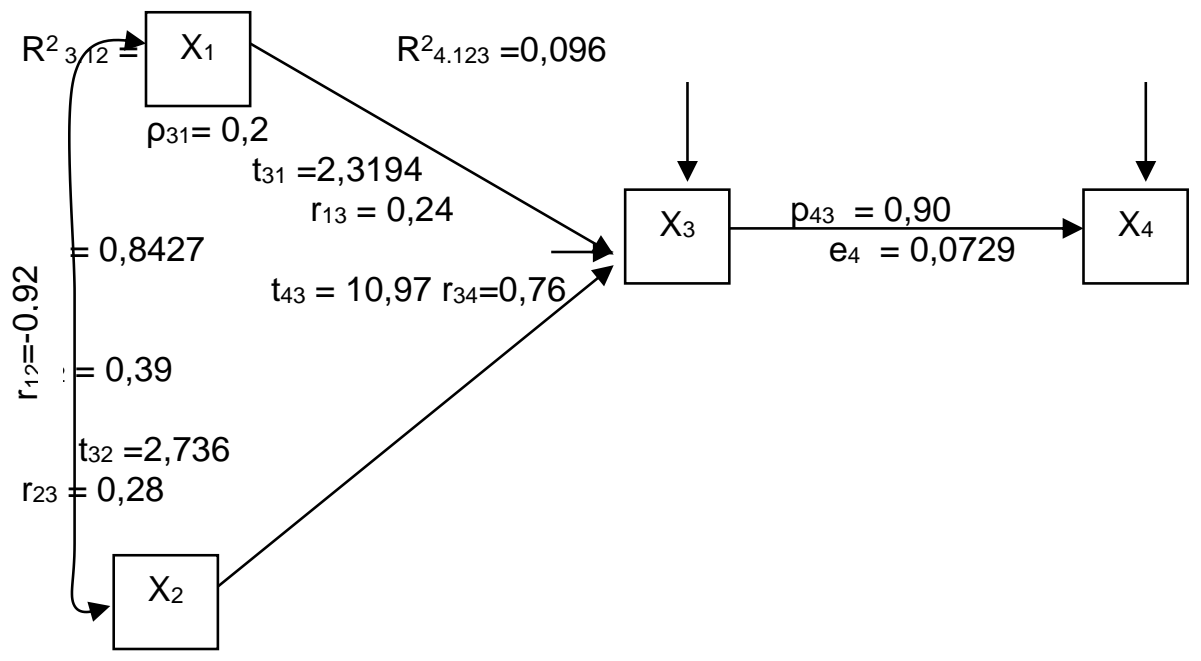

Organizational Culture Path Diagram (X1) and Work Commitment (X2) Management Knowledge (X3) on Achievement Motivation (X4).

\section{Conclusion}

This study produces ten conclusions, namely, including: 1). There is a direct influence of organizational culture $\left(\mathrm{X}_{1}\right)$ on employee achievement motivation (X4). Based on the results of the calculation of the analysis obtained tcount $(18,31)>\mathrm{t}$ table (1.969), so that H0 is rejected and H1 is accepted. It means that organizational culture has a significant influence on employee achievement motivation. 2). There is a direct effect of work commitment $\left(\mathrm{X}_{2}\right)$ on employee achievement motivation $\left(\mathrm{X}_{4}\right)$. Based on the results of the calculation of the analysis obtained the 
value of tcount (7.61)> t table (1.969), so that $\mathrm{H} 0$ is rejected and $\mathrm{H} 1$ is accepted. It means that the work commitment that develops in the institution has a significant influence on employee achievement motivation. 3). There is a direct influence of organizational culture $\left(\mathrm{X}_{1}\right)$ and work commitment $\left(\mathrm{X}_{2}\right)$ on employee achievement motivation $\left(\mathrm{X}_{4}\right)$. Based on the results of the calculation of the analysis obtained the value of Fcount (16.36) >Ftable (3.45), so that H0 is rejected and $\mathrm{H} 1$ is accepted. Meaning that the organizational culture and high management knowledge in the institution have a significant influence on employee achievement motivation.

The conclusion of the study is, from the results of testing the hypothesis, it can be concluded that the 10 hypotheses are accepted, namely there are effects of exogenous variables on endogenous variables both partially and simultaneously, both directly and indirectly. The research implication is that an employee's achievement motivation is strongly influenced by organizational culture, work commitment, and management knowledge, the better the organizational culture, the higher the work commitment and management knowledge, the higher the spirit of achievement in carrying out a job.

\section{References}

[1] A.B.Susantodkk.A. Strategic Management, Corporate Culture \& Organizational Culture Jakarta: The Jakarta Consulting Group, 2008.

[2] Abu DawudSulaiman bin Al-Asy'as al-Sijistani, SunanAbiDawud, ditashiholeh Muhammad Nasiruddin al-Albani (al-Riyaadh: Maktabah al-Ma'arif. 1424

[3] Andrew j. Elliot dan Carol S. Dweck, Handbook of Compentence and Motivation New York: The Guilford Press, 2005

[4] Anita Wolfook, Educational Psychology, Printreintheunited states of america, 2007

[5] Bobbi Deporterdan Mike Henaki, Quantum Bisnis: MembiasakanBerbisnisSecaraEtisdanSehat. Bandung: Kaifa, 2000

[6] Chistopher F. Achua, D.B.A dan Robert N. Lussier, Effective Leadership Canada: SouthWestern, 2010.

[7] Daniel Coleman. KecerdasanEmosionaluntukMencapaiPuncakPrestasi. Terjemahan Alex TrikantjoroWidodo. Jakarta: Gramedia, 1999.

[8] Dean Anderson dan Linda S. Ackerman Anderson.Beyond Change Management. San Francisco: Jossey-Bass, 2001.

[9] DjaalidanPudjiMuljono, PengukurandanBidangPendidikan.Jakarata: PPs UNJ, 2012.

[10] Evans dan Lindsay, The Management And Control Of Quality Canada: South-Western. 2008

[11] Fred Luthans, PrilakuOrganisasi, edisibahasa Indonesia olehVivin. shekarArie, danWinong. Yogyakarta: Andi, 2006.

[12] GeryDessler, Human Resource Management, Ninth Ed. New Jersey: Prentice Hall. 2003

[13] HusainiUsman. Dkk. MetodologiPenelitianSosial.(Jakarta: PT. BumiAksara. 2009.

[14] IndraDjatiSidi.PendidikandanPeran Guru Dalam Era Globalisasi. Jakarta: Artikel, 2010

[15] Iskandar, MetodologiPenelitianPendidikandanSosial, (Jakarta: GaungPersada Press, 2009

[16] James R.Egvans, William M LiNdsay,TheManagemen And Control Of Quallity, Copright 2008

[17] Jhon M. Ivancevich and Micheal T Matteson, Organizational Behavior and Management, (New Jersey: McGraw-Hil, 2002)

[18] John W Creswell., Educational Research, Planning, Conducting, and Evaluating Quantitative and Qualitative Research,(Amerika: Pearson Merrill Prentice Hall, 2008

[19] John W. Creswell, Education Research Planning, Conducting and Evaluating Quantitative and Qualitative Research (Boston: Pearson, 2012) 
[20] John W. Creswell, Educational Reserach: Planning, Conducting, and Evaluating Quantitative and Qualitatitive Research, (NJ: Merril Prentice Hall, 3rd ed, 2008),

[21] Jon R Katzenbach, Peak Performance, (USA : Harvard Business School Press, 2000),

[22] K. Bertens, Etika, (Yogyakarta:Kanisius, 2013)

[23] K. Praveen Parboteeah John B. Cullen, Strategic International Management (Canada: SouthWestern, Cengage Learning, 2011)

[24] Kementerian Agama Republik Indonesia, Alqurandanterjemahannya (Bandung: 2013)

[25] L.R. Gay dkk, Educational Research Competencies for Analysis and Application, (New Jersey, Pearson Education, 2009)

[26] Larry J. Raynolds, kiatsuksesManajemenBerbasisSekolah, (Jakarta: CV. Diva Pustaka, 2005)

[27] MasanaSembiring, BudayadanKinerjaOrganisasi, (Bandung: Fokus Media, 2012),

[28] McClelland, D. Human Motivation. (New York: Cambridge University Press, 1987)

[29] Mulyasa. 2005. Menjadi Guru Profesional. (Bandung: RemajaRosdakarya, 2015),

[30] Neil H. James Snyder dan James J.Dowd, Dianne Houghton.Vision, Values, and Courage Leadership for Quality Management. (New York: The Free Press, 1994),

[31] Nicholls, J. G. (1984). Achievement Motivation: Conception of Ability, Subjec-tive Experience, Task Choice, and Performance. (Psychological Review 91, 1984)

[32] Nonaka, I and H Takeuchi .The Knowledge Creating Company: How Japanese Companies Create the Dynamics of Innovation. (Oxford: Oxford University Press, 1995),

[33] Pintrich, P. R., \& De Groot, E. V. (1990).Motivational and Self-Regulated Learning Component of Classroom.

[34] Pramudyo, C.S,2007, Perancangan Model Fungsi Collaborative Knowledge Retrieval PadaManajemenPengetahuan (StudiKasus: UIN SunanKalijaga Yogyakarta), Tesis, ITB, Bandung

[35] RiduwandanEngkosAchmadKuncoro, Cara MenggunakandanMemaknai Path Analysis, (Bandung: Alfabeta 2013),

[36] Ridwan, Path Analysis, (Bandung: CV. Alfabeta,2013),

[37] Robert Kreitnerdan Angelo Kinicki, OrganizaationBehavior (Printed in China: McGraw Hill, 20070

[38] Robert Kreitnerdan Angelo Kinicki, Organizational Behavior (Boston: Irwin Homewood II, 1991)

[39] Robert P. Vecchio., Organizational Behavior, (Orlando: Harcourt Brace \& Company, 1995)

[40] S. P Siagian,.. ManajemenSumberDayaManusia. (Jakarta: BumiAksara, 2012)

[41] Salam Burhanuddin,. 2007. PengantarPedagogik (dasar-dasarilmumendidik). (Jakarta : Rineka Cipta, 2007)

[42] Sambas Ali MuhidindanMamanAbdurahman, AnalisisKorelasi, Regresi, danJalurdalamPenelitian, (Bandung: PustakaSetia 2007)

[43] Schunk, D. H., Pintrich, P. R., \&Meece, J. L. (2008). Motivation in Education, Theory, Research, and Applications.Third Edition. New Jersey: Pearson Educatuon, Inc

[44] Steephen P Robbins, PerilakuOrganisasi, TerjemahanHadyanaPujaatmaka, (Jakarta: PT. Prehalindo, 1996)

[45] Steers, R. M dan Porter, L.W. 1983.Motivation and Work Behavior. (USA: Mc. Graw,1983),

[46] Stephen P. Robbins dan Mary COULTER, Management (Pearson, 2012)

[47] SudarmanDanim, Pedagogi, Andragogi, danHeutagogi (Bandung: Alfabeta, 2010),

[48] Sugiono, MetodePenelitianAdministrasi, (Bandung :Alfabeta, 2012),

[49] Sugiono, MetodePenelitianPendidikan,:PendekatanKuantitatif, Kualitatif, dan R \& D, (Bandung: Alfabeta, 2006),

[50] Sugiyono, MetodologiPenelitianPendidikan, (Bandung :Alfabeta, 2007), hal. 118

[51] Turban, E., Aronson, J.E,2001, Decision Support System And Intelligent Systems, Prentice Hall International Edition, New Jersey, USA

[52] UlberSilalahi, MetodePenelitianSosial, (Bandung: RefikaAditama, 2010), 
[53] Woo, et.all, Organizational Behavior, A Global Perspective, (Australia: Jhon Willey \& Sons, 2001)

[54] DisertasiMamik.PengaruhKedisiplinan, Motivasi Kerjadan Komitmen Organisasi Terhadap Kepuasan Kerja Karyawan

[55] DisertasiNoorhafezaHerlianiAdeydanFerlisHj. Bahari Hubunganantarakecerdasanemosi, kepuasankerjadankomitmenterhadaporganisasi

[56] DisertasiAchmad Tri KurniawanBahtiarHubunganantarakomitmenorganisasi, sikap entrepreneurship, danpengetahuantentangstrategiorganisasidengankeunggulanbersainggurudisekolah AlAzharsyifabudi Jakarta (2009),

[57] Disertasi Benyamin SitumorangThe Effect of Instructional Leadership, Knowledge of Educational; Management, Interpersonal Communication and job Satisfaction to Organization Commitment of the Senior High School Principals (A Case Study in Senior High Schools in Medan Municipality

[58] DisertasiDearlianaSinagaPengaruhPengaruhAntaraMotifasiBerprestasi, KepuasanKerja, Komitmen Kerja Terhadap Kinerja Pimpinan. 2006

[59] Undang-undangNomor 5 Tahun 2014 tentangAparatur Sip 